\title{
ANALISIS KEPUASAN PELANGGAN TERHADAP HASIL PENGEMBANGAN PRODUK LAMPU RUMAH DENGAN METODE QUALITY FUNCTION DEPLOYMENT (QFD)
}

\author{
Achmad Fatahilah', ${ }^{1}$ Trismawati ${ }^{2}$, Tri Prihatiningsih ${ }^{3}$ \\ 1,2,3 Jurusan Teknik Industri, Universitas Panca Marga, Jl. Yos Sudarso, Probolinggo 67271, Indonesia \\ achmadfatahilah@gmail.com
}

\begin{abstract}
Abstrak. Penelitian ini bertujuan untuk mengetahui kepuasan pelanggan terhadap hasil produk pengembangan lampu rumah berbasis mikrokontroler arduino yaitu produk lampu Fathlamp. Produk lampu fathlamp adalah produk lampu LED yang bisa dikendalikan dengan jarak jauh menggunakan smartphone android sebagai sakelar dengan memanfaatkan jaringan wifi. Dalam menganalisis kepuasan pelanggan, peneliti menggunakan metode QFD (Quality Function Deployment).
\end{abstract}

Penelitian ini merupakan penelitian studi kasus yang dilakukan dengan pengambilan data melalui kuesioner, wawancara, dan dokumentasi. Subjek penelitian adalah konsumen pengguna lampu rumah dan data kuantitatif diolah secara deskriptif.

Hasil penelitian menunjukkan bahwa hasil kepuasan pelanggan terhadap atribut produk lampu fathlamp yaitu konsumsi energi listrik lebih hemat dengan prosentase sebesar 18,88\%, perawatan yang mudah dengan prosentase sebesar $17,48 \%$, mudah dalam penggunaannya dengan prosentase sebesar $16,16 \%$, bahan yang awet dan tahan lama dengan prosentase sebesar $14,11 \%$, kecerahan cahaya dengan prosentase sebesar $12,9 \%$, desain yang sederhana dengan prosentase sebesar 11,03\%, harga yang terjangkau dengan prosentase sebesar $9,44 \%$.

Kata kunci : Quality Function Deployment (QFD), Fathlamp.

\section{PENDAHULUAN}

Lampu adalah sebuah alat penerangan yang sangat penting untuk digunakan dalam kehidupan sehari-hari. Lampu yang sering digunakan oleh masyarakat pada saat ini adalah lampu TL atau yang biasanya disebut lampu neon. Lampu TL atau yang lebih dikenal dengan lampu neon adalah lampu listrik yang memanfaatkan gas neon dan lapisan Fluorescent sebagai pemendar cahaya pada saat dialiri arus listrik (Muhaimin, 2001). Dalam pemakaiannya, masyarakat mempunyai keluhan tentang kekurangan lampu TL yang digunakan setiap hari dan mengharapkan adanya suatu produk baru yang akan mempunyai kelebihan dari lampu sebelumnya, berdasarkan hasil survey yang dilakukan peneliti, berikut keluhan konsumen tentang lampu TL yang selama ini digunakan:

1. Penggunaan daya listrik pada Lampu TL atau lampu neon cenderung lebih boros energi dikarenakan membutuhkan daya listrik tinggi untuk menyalakannya.
2. Kecerahan cahaya pada lampu TL cenderung silau mata dan cepat redup.

3. Mudah pecah jika lampu TL tidak sengaja jatuh dikarenakan bahan dari lampu TL sendiri adalah terbuat dari kaca.

4. Perawatan lampu TL sangat sulit karena sekali pakai dan tidak dapat diperbaiki.

5. Umur pemakaian lampu TL yang cenderung lebih singkat.

6. Tombol On-Off yang digunakan pada saat ini masih dilakukan secara manual menggunakan saklar tembok dimana ketika pemilik rumah pada malam hari tidak berada didalam rumah maka keadaan lampu rumah akan mati.

Dengan adanya keluhan konsumen yang sudah diterangkan diatas, maka peneliti membuat produk Fathlamp. Fathlamp adalah produk lampu yang dapat dikendalikan dengan jarak jauh menggunakan smartphone android sebagai sakelar memanfaatkan jaringan wifi, Untuk pengolahnnya digunakan mikrokontroler ESP8266 sedangkan untuk outputnya berupa produk lampu rumah led 15 watt. Seberapa 
besar kepuasan pelanggan terhadap produk lampu fathlamp setelah mencoba produk inilah yang menjadi bahan penelitian.

Pada permasalahan penelitian ini, peneliti akan menggunakan Metode Quality Function Deployment (QFD) untuk mengukur kepuasan pelanggan terhadap produk lampu fathlamp yang sudah ada.

\section{METODE PENELITIAN}

\section{Populasi dan sample}

Populasi dari penelitian ini adalah warga masyarakat Probolinggo dan sekitarnya. Sampel atribut dalam hal ini adalah populasi dari pengguna lampu rumah yang berada di wilayah Probolinggo. Dalam menentukan jumlah sampel digunakan perhitungan dengan rumus Bernouli dengan ukuran sampel minimum untuk menguji kecukupan data kuesioner. Rumus dalam perhitungan Bernouli (Edi,2016) adalah sebagai berikut:

$$
N \geq \frac{\left(Z_{a / 2}\right)^{2} p \cdot q}{e^{2}}
$$

Keterangan :

$$
\begin{aligned}
\mathrm{N} & =\text { Jumlah sampel minimum } \\
\mathrm{Z} & =\text { Nilai distribusi normal } \\
\alpha & =\text { Tingkat signifikan } \\
\mathrm{p} & =\text { Proporsi jumlah kuesioner yang } \\
& \text { dijawab benar } \\
\mathrm{q}= & 1-\mathrm{p}, \text { proporsi jumlah kuesioner yang } \\
& \text { dijawab salah } \\
\mathrm{e} & =
\end{aligned}
$$

Tahap ini merupakan penentuan jumlah sampel minimum kuesioner dengan $\alpha=0.05$ yang akan digunakan pada tahap selanjutnya, kuesioner pada tahap pertama disebarkan kepada 30 responden penguna lampu rumah di daerah Kota Probolinggo. Dari 30 kuesioner tahap pertama yang disebarkan terdapat satu kuesioner yang tidak terisi dengan benar, sehingga terdapat 29 kuesioner yang dianggap benar dan dapat dilakukan pengolahan pada tahap selanjutnya.

$$
\begin{aligned}
N & =\frac{\left(Z_{0.05 / 2}\right)^{2}(29 / 30) \cdot(1 / 30)}{0.05^{2}} \\
& =\frac{(1.96)^{2}(0.96) .(0.03)}{0.0025} \\
& =\frac{0.1106}{0.0025} \\
& =44.24 \\
& =44
\end{aligned}
$$

Jadi jumlah sampel minimum yang harus diambil pada penelitian ini adalah 44 responden.

\section{Metode penelitian}

\section{a. Metode Pengumpulan Data}

Pengumpulan data awal yang dilakukan di lokasi (obyek penelitian) secara langsung yaitu:

1. Wawancara

2. Kuesioner

\section{b. Metode perancangan}

Cara atau teknik yang digunakan dalam pengumpulan data adalah dengan menggunakan kuesioner yang melalui beberapa tahapan diantaranya adalah:

1. Penyusunan dan penyebaran kuisioner Pada tahap ini kuesioner terbuka bertujuan untuk mengidentifikasi tingkat kepuasan, kepentingan dan harapan konsumen terhadap produk fathlamp.

2. Menyusun House of Quality (Rumah Mutu)
a. Respon Teknis
b. Relationship Matrix
c. Korelasi Teknis
d. Hasil HOQ

3. Analisis Dan Intrepretasi

\section{HASIL DAN PEMBAHASAN \\ Analisis Deskriptif}

a. Karakteristik Responden

Karakteristik responden diperlukan dalam penelitian ini yang bertujuan untuk mengetahui keterkaitan antara konsumen dengan penilaian terhadap atribut-atribut produk lampu fathlamp. Responden yang digunakan dalam penelitian ini berjumlah 44 orang. Karakteristik umum responden dalam penelitian ini dapat ditunjukkan dari usia, jenis kelamin, pendidikan dan pekerjaan. Data hasil penelitian tentang karateristik reponden menurut usia, jenis kelamin, pendidikan dan pekerjaan yang secara rinci dapat dilihat di bawah ini

\section{b. Jenis Kelamin}

Hasil penyebaran kuesioner penelitian terhadap 44 responden produk lampu fathlamp diketahui bahwa sebanyak 17 orang responden berjenis kelamin perempuan dan sisanya sebanyak 27 orang adalah jenis kelamin laki-laki. Karakteristik responden berdasarkan jenis kelamin dapat dilihat pada tabel 1. 
Tabel 1. Karakteristik Responden Berdasarkan Jenis Kelamin

\begin{tabular}{|l|l|c|c|}
\hline \multirow{2}{*}{ Karakteristik } & \multirow{2}{*}{ Kategori } & \multicolumn{2}{|c|}{$\mathrm{N}=44$} \\
\cline { 3 - 4 } & & $\mathrm{N}$ & $\%$ \\
\hline Jenis & Laki-laki & 27Orang & $61,3 \%$ \\
Kelamin & Perempuan & 17Orang & $38,7 \%$ \\
\hline
\end{tabular}

\section{c. Usia}

Responden yang menggunakan produk lampu rumah berasal dari beragam usia. Berdasarkan 44 orang responden, diperoleh informasi bahwa responden terhadap kepuasan produk lampu fathlamp sebagian besar berusia 15-25 tahun yaitu sebanyak 17 orang (Tabel 2).

Tabel 2. Karakteristik Responden Berdasarkan Usia

\begin{tabular}{|l|c|c|r|}
\hline \multirow{2}{*}{ Karakteristik } & \multirow{2}{*}{ Kategori } & \multicolumn{2}{|c|}{$\mathrm{N}=44$} \\
\cline { 3 - 4 } & & $\mathrm{N}$ & $\%$ \\
\hline Usia & 15-25 Tahun & 17Orang & $38,6 \%$ \\
& 26-35 Tahun & 8 Orang & $18,2 \%$ \\
& 36-45 Tahun & 8 Orang & $18,2 \%$ \\
& 46-55 Tahun & 8 Orang & $18,2 \%$ \\
& 56-75 Tahun & 8 Orang & $6,8 \%$ \\
\hline
\end{tabular}

\section{d. Pendidikan}

Berdasarkan 44 responden, diperoleh hasil informasi pendidikan responden terhadap kepuasan penggunaan produk lampu fathlamp adalah sebagian besar berpendidikan Sekolah Menengah Atas (SMA) sebanyak 21 Orang.

Tabel 3. Karakteristik Responden Berdasarkan Pendidikan

\begin{tabular}{|l|l|r|r|}
\hline \multirow{2}{*}{ Karakteristik } & \multirow{2}{*}{ Kategori } & \multicolumn{2}{|c|}{$\mathrm{N}=44$} \\
\cline { 3 - 4 } & & $\mathrm{N}$ & $\%$ \\
\hline Pendidikan & SD & 14 Orang & $31,8 \%$ \\
Terakhir & SMP & 5 Orang & $11,4 \%$ \\
& SMA & 21 Orang & $47,7 \%$ \\
& PT & 4 Orang & $9,1 \%$ \\
\hline
\end{tabular}

\section{e. Pekerjaan}

Berdasarkan 44 orang responden diperoleh informasi bahwa sebagian besar responden terhadap kepuasan penggunaan produk lampu fathlamp berstatus sebagai karyawan swasta.

Tabel 4. Karakteristik Responden Berdasarkan

\begin{tabular}{|l|l|r|r|}
\hline \multirow{2}{*}{ Karakteristik } & \multirow{2}{*}{ Kategori } & \multicolumn{2}{|c|}{$\mathrm{N}=44$} \\
\cline { 3 - 4 } & & $\mathrm{N}$ & $\%$ \\
\hline Pekerjaan & IRT & 11 Orang & $25,0 \%$ \\
& Swasta & 20 Orang & $45,5 \%$ \\
& Buruh & 7 Orang & $15,9 \%$ \\
& Mahasiswa & 3 Orang & $6,8 \%$ \\
& PNS & 3 Orang & $6,8 \%$ \\
\hline
\end{tabular}

Analisis Quality Function Deployment (QFD) a. Pengumpulan Data Hasil survey terhadap kepuasan konsumen

Peneliti melakukan penyebaran kuesioner kepada 44 orang dengan sample yang sama yaitu customer yang terdaftar di survey awal. Tujuan kegiatan survey akhir ini yaitu untuk mengetahui apakah hasil produk pengembangan lampu rumah yang sudah dirancang sesuai dengan apa yang di inginkan oleh customer dan bisa diterima oleh customer atau tidak.

Tabel 5. Data Atribut Produk Fathlamp

\begin{tabular}{|c|l|}
\hline No. & \multicolumn{1}{|c|}{ Atribut } \\
\hline 1. & Desain Sederhana \\
\hline 2. & Kecerahan Cahaya \\
\hline 3. & Harga \\
\hline 4. & Bahan \\
\hline 5. & Konsumsi Energi \\
\hline 6. & Perawatan \\
\hline 7. & Mudah Dalam penggunaan \\
\hline
\end{tabular}

Data hasil kuesioner dari survey akhir yang diperoleh dengan wawancara langsung pada customer, kemudian diolah dan dirangkum untuk dijadikan dasar dalam membuat Voice of Customer (VOC) tentang hasil rancangan produk lampu rumah yaitu lampu fathlamp. Atribut sama dengan survey awal dan dilakukan penyebaran kuisioner. Dimana kuesioner menggunakan skala linket 1-5. Adapun data dari hasil kuesioner yang dilakukan terhadap hasil produk lampu rumah dapat dilihat pada tabel 6 di bawah ini 
Tabel 6. Data jumlah responden terhadap atribut hasil Produk Lampu Rumah

\begin{tabular}{|c|l|c|c|c|c|c|}
\hline \multirow{2}{*}{ No. } & \multicolumn{2}{|c|}{ Atribut } & \multicolumn{5}{|c|}{ Tingkat Kepentingan (Banyaknya Responden) } \\
\cline { 3 - 7 } & & Tidak Puas & $\begin{array}{c}\text { Kurang } \\
\text { Puas }\end{array}$ & $\begin{array}{c}\text { Cukup } \\
\text { Puas }\end{array}$ & Puas & $\begin{array}{c}\text { Sangat } \\
\text { Puas }\end{array}$ \\
\cline { 3 - 7 } & $(1)$ & $(2)$ & $(3)$ & $(4)$ & $(5)$ \\
\hline 1. & Desain Sederhana & & 14 & 30 & & \\
\hline 2. & Kecerahan Cahaya & & 9 & 20 & 15 & \\
\hline 3. & Harga & 8 & 15 & 21 & & \\
\hline 4. & Bahan & 2 & 5 & 18 & 10 & 9 \\
\hline 5. & Konsumsi Energi & & & 4 & 10 & 30 \\
\hline 6. & Perawatan & & & 5 & 23 & 16 \\
\hline 7. & $\begin{array}{l}\text { Mudah Dalam } \\
\text { penggunaan }\end{array}$ & & & 13 & 21 & 10 \\
\hline
\end{tabular}

IR (Importance Rating) adalah Gap customer didapatkan dari rata-rata jawaban responden.

Tabel 7. Data IR terhadap Atribut Hasil Produk Lampu Rumah

\begin{tabular}{|c|l|c|}
\hline No. & \multicolumn{1}{|c|}{ Atribut } & IR \\
\hline 1. & Desain Sederhana & 3 \\
\hline 2. & Kecerahan Cahaya & 3 \\
\hline 3. & Harga & 3 \\
\hline 4. & Bahan & 3 \\
\hline 5. & Konsumsi Energi & 5 \\
\hline 6. & Perawatan & 4 \\
\hline 7. & Mudah Dalam penggunaan & 4 \\
\hline
\end{tabular}

\section{b. Karakteristik Teknis}

Bagian ini merupakan definisi secara teknis kepuasan konsumen yang berhubungan dengan hasil perancangan produk lampu rumah yang sudah dilakukan. Karakteristik teknis dari peneliti untuk atribut hasil perancangan produk lampu yang sudah dilakukan dapat di lihat pada table 8 .

Tabel 8. Data Karakteristik Teknis

\begin{tabular}{|c|l|l|}
\hline No. & \multicolumn{1}{|c|}{ Atribut } & \multicolumn{1}{c|}{ Karakteristik Teknis } \\
\hline 1. & $\begin{array}{l}\text { Desain } \\
\text { Sederhana }\end{array}$ & Desain bagus, sederhana \\
\hline 2. & $\begin{array}{l}\text { Kecerahan } \\
\text { Cahaya }\end{array}$ & Lampu terang \\
\hline 3. & Harga & Harga terjangkau \\
\hline 4. & Bahan & Awet dan tahan lama \\
\hline 5. & $\begin{array}{l}\text { Konsumsi } \\
\text { Energi }\end{array}$ & $\begin{array}{l}\text { Penggunaan listrik } \\
\text { minim }\end{array}$ \\
\hline 6. & Perawatan & Mudah \\
\hline
\end{tabular}

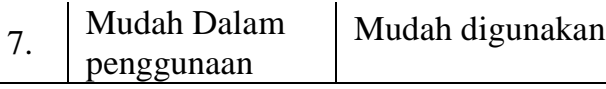

\section{c. Perhitungan tingkat kepuasan konsumen}

Pengukuran tingkat kepuasan konsumen terhadap hasil produk dimaksudkan untuk mengukur bagaimana kepuasaan konsumen tentang hasil produk yang sudah dibuat oleh peneliti. Pengukuran kepuasan konsumen sangatlah penting untuk hasil produk yang sudah dirancang, dari hasil pengukuran inilah peneliti dapat mengetahui bagian-bagian mana yang perlu dikembangkan kembali untuk diperbaiki.

Dihitung dengan rumus (Fithri,2014):

$$
W A P=\frac{\sum(N R V)}{(T R)}
$$

Keterangan :

WAP : Weight Average Performance

NRV : Number of Respondent Value

TR : Total of Respondent 
Untuk hasil perhitungan tingkat kepuasan konsumen dari atribut dapat dilihat tabel 9

Tabel 9. Tingkat kepuasaan konsumen

\begin{tabular}{|c|c|c|c|c|c|c|c|}
\hline \multirow{3}{*}{ Atribut } & \multicolumn{5}{|c|}{ Hasil Kuesioner } & \multirow{3}{*}{$\begin{array}{l}\text { Total } \\
\text { score }\end{array}$} & \multirow{3}{*}{$\begin{array}{c}\text { Tingkat } \\
\text { kepuasaan }\end{array}$} \\
\hline & \multicolumn{5}{|c|}{ Skala pengukuran } & & \\
\hline & 1 & 2 & 3 & 4 & 5 & & \\
\hline Desain Sederhana & & 14 & 30 & & & 118 & 1.18 \\
\hline Kecerahan Cahaya & & 9 & 20 & 15 & & 138 & 1.38 \\
\hline Harga & 8 & 15 & 21 & & & 101 & 1.01 \\
\hline Bahan & 2 & 5 & 18 & 10 & 9 & 151 & 1.51 \\
\hline Konsumsi Energi & & & 4 & 10 & 30 & 202 & 2.02 \\
\hline Perawatan & & & 5 & 23 & 16 & 187 & 1.87 \\
\hline Mudah Dalam penggunaan & & & 13 & 21 & 10 & 173 & 1.73 \\
\hline
\end{tabular}

d. Hubungan Respon Teknis terhadap VOC survey akhir

Setelah diketahui karakteristik-karakteristik dari data Voice of Customer (VOC). karakteristik-karakteristik tersebut akan di cari korelasi atau hubungan antara VOC dengan Technical Response. Tujuannya adalah Untuk mengetahui seberapa besar hubungan antara respon teknis dan VOC. Penentuan kuat tidaknya antara kebutuhan teknik dengan suara konsumen memerlukan pengalaman, ketajaman dan pengetahuan yang cukup mendalam tentang segala sesuatu yang terkait dengan hasil pengembangan produk lampu rumah, banyak hal-hal yang tidak bisa dipastikan begitu saja, namun memerlukan beberapa kali percobaan untuk mengetahui penyebabnya. Kriteria score dapat dilihat di bawah ini:

Tabel 10. Lambang dan nilai hubungan antar VOC dan karakteristik teknis

\begin{tabular}{|c|c|c|}
\hline \multicolumn{3}{|c|}{ Relationship Matrix } \\
\hline Tidak ada & 0 & \\
\hline Lemah & 1 & 0 \\
\hline Sedang & 3 & \\
\hline Kuat & 9 & $\bigcirc$ \\
\hline
\end{tabular}

Tabel 11. Hubungan respon teknis terhadap VOC

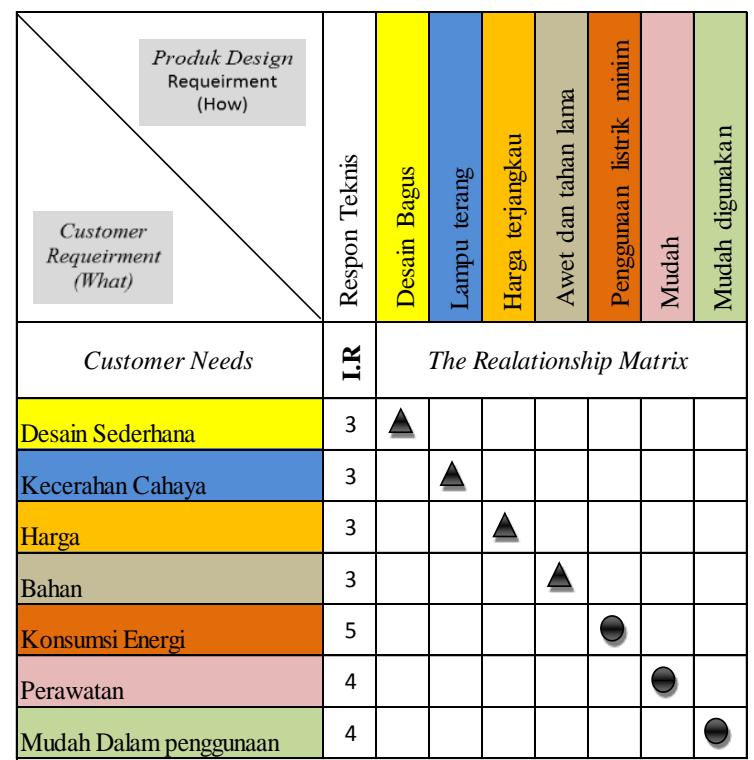

Selanjutnya membuat matrik perencanaan. Pada matrik ini peneliti dapat mengetahui tentang tingkat rencana pengembangan produk yang akan peneliti inginkan dan juga mengetahui tingkat keinginan konsumen tentang produk lampu rumah yang telah ada. Untuk lebih jelasnya dapat dilihat di Tabel 12 sebagai berikut: 
Tabel 12. Matrix Perencanaan

\begin{tabular}{|c|c|c|c|c|c|c|c|c|}
\hline & 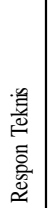 & 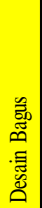 & 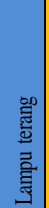 & 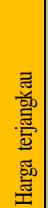 & 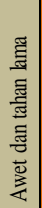 & 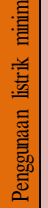 & 急 & 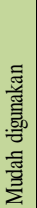 \\
\hline Customer Needs & $\cong$ & \multicolumn{7}{|c|}{ The Realationship Matrix } \\
\hline Desain Sederhana & 3 & 3 & 0 & 0 & 0 & 0 & 0 & 0 \\
\hline Kecerahan Cahaya & 3 & 0 & 3 & 0 & 0 & 0 & 0 & 0 \\
\hline Harga & 3 & 0 & 0 & 3 & 0 & 0 & 0 & 0 \\
\hline Bahan & 3 & 0 & 0 & 0 & 3 & 0 & 0 & 0 \\
\hline Konsumsi Energi & 5 & 0 & 0 & 0 & 0 & 9 & 0 & 0 \\
\hline Perawatan & 4 & 0 & 0 & 0 & 0 & 0 & 9 & 0 \\
\hline Mudah Dalam penggunaan & 4 & 0 & 0 & 0 & 0 & 0 & 0 & 9 \\
\hline
\end{tabular}

\section{Matrik Hubungan Korelasi antar Respon} Teknik

Hubungan antar VOC dapat dilihat pada Gambar 1 di bawah ini untuk mengetahui seberapa besar hubungan antar respon teknis. Kriteria score dapat dilihat di bawah ini:

Tabel 13. Lambang dan nilai hubungan antar karakteristik teknis

\begin{tabular}{|c|c|}
\hline \multicolumn{2}{|c|}{ Correlation } \\
\hline Strong + & $\bigcirc$ \\
\hline Positive & \\
\hline None & \\
\hline
\end{tabular}

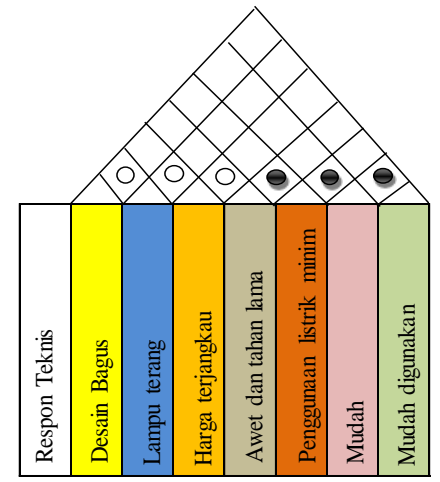

Gambar 1. Optimasi matrik atap

\section{Hasil House of Quality (HOQ) Hasil produk Lampu Rumah}

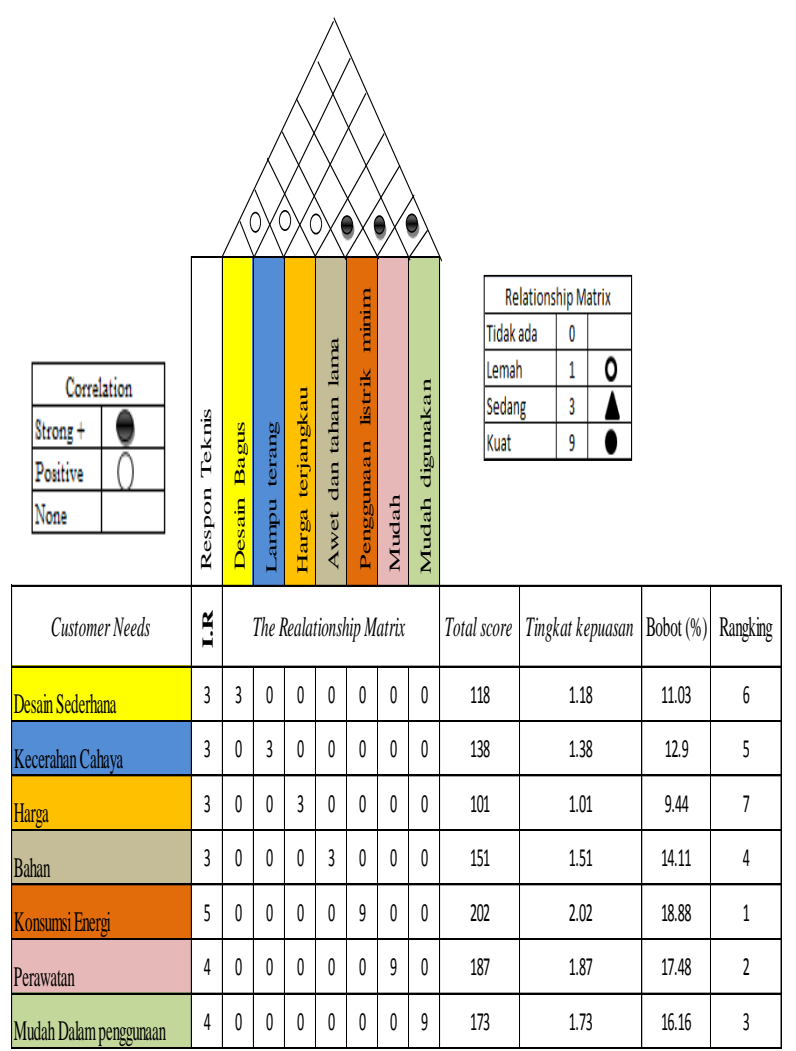

Gambar 2. Hasil HOQ perancangan produk

Berdasarkan hasil analisis matrik HOQ di atas didapatkan bahwa hasil perhitungan bobot dan perengkingan sebagai berikut:

Tabel 14. Hasil kepuasan konsumen terhadap hasil produk lampu

\begin{tabular}{|l|l|l|c|c|c|}
\hline No. & Atribut & Respon teknis & Ranking & $\begin{array}{l}\text { Tingkat } \\
\text { kepuasaan }\end{array}$ & Bobot (\%) \\
\hline 1. & Konsumsi Energi & Penggunaan listrik minim & 1 & 2.02 & 18,88 \\
\hline 2. & Perawatan & Mudah & 2 & 1.87 & 17,48 \\
\hline 3. & $\begin{array}{l}\text { Mudah Dalam } \\
\text { penggunaan }\end{array}$ & Mudah digunakan & 3 & 1.73 & 16,16 \\
\hline
\end{tabular}




\begin{tabular}{|l|l|l|c|c|c|}
\hline 4. & Bahan & Awet dan tahan lama & 4 & 1.51 & 14,11 \\
\hline 5. & Kecerahan Cahaya & Lampu terang & 5 & 1.38 & 12,90 \\
\hline 6. & Desain Sederhana & Desain bagus & 6 & 1.18 & 11,03 \\
\hline 7. & Harga & Harga terjangkau & 7 & 1.01 & 9,44 \\
\hline
\end{tabular}

\section{KESIMPULAN}

Berdasarkan hasil analisis yang telah dilakukan, maka dapat diambil kesimpulan bahwa kepuasan konsumen terhadap produk fathlamp berdasarkan atribut antara lain, konsumsi energi listrik lebih hemat dengan prosentase sebesar $18,88 \%$, perawatan yang mudah dengan prosentase sebesar17,48\%, mudah dalam penggunaannya dengan prosentase sebesar $16,16 \%$, bahan yang awet dan tahan lama dengan prosentase sebesar $14,11 \%$, kecerahan cahaya dengan prosentase sebesar 12,9\%, desain yang sederhana dengan prosentase sebesar $11,03 \%$, harga yang terjangkau dengan prosentase sebesar $9,44 \%$.

\section{DAFTAR PUSTAKA}

[1] Edy, Evi Yuliawati. 2016. Pengembangan produk lampu meja belajar dengan metode kano dan Quality function deployment (QFD). Intstitu Teknologi Adhi Tama. Surabaya.

[2] Dewi Setya Purwani. (2013). penerapan metode Qfd (Quality Function Deployment) pada unit usaha di Smkn 2 Yogyakarta. Laporan Penelitian. UNY Yogyakarta.

[3] Fithri, N. Poppy Indriayani, Desi Kusmindari. 2014. Pengembangan emergency lamp dengan led luxeon menggunakan metode Quality function deployment (QFD). Universitas Bina Darma. Jakarta.

[4] Hidayatulloh, Rahmat. 2010. Studi Ergonomi Perancangan dan Pengembangan Produk Tongkat Lansia dengan Metode Quality Function Deployment ( QFD ). Jember.

[5] Jono. 2006. Implementasi metode Quality Funtion Deployment (QFD) guna meningkatkan qualitaskain batik tulis, Jurusan Teknik Industri, Universitas Widya Mataram Yogyakarta.
[6] Muhaimin. 2001. Teknologi Pencahayaan. Refika aditama. Bandung.

[7] Jaelani, E. 2009. Quality Function Deployment (QFD). [on line]. www.eje. blogspot.com. [27 September 2018]

[8] Uswatun. 2007. Penerapan konsep quality function deployment (QFD) dalam meningkatkan kualitas dan mengembangkan produk sepeda motor honda karisma 125D. Laporan Penelitian. UNNES Semarang.

[9] Wijaya, Tony. 2011. Manajemen Kualitas Jasa: Desain Servqual, QFD, dan Kano: Disertai Contoh Aplikasi dalam Kasus Penelitian. Jakarta: PT Indeks.

[10] Zuliantoni, 2006, Pengembangan produk alat penangkap ular denngan metode QFD, Faculty of Industrial Technologi, Sepeluh Nopember Institute of Technology Surabaya. 